\title{
Livable Rental Houses for Factory Workers in Industrial Area
}

\author{
Rahardiyan Ari Wicahyo, Dewi Septanti, and Rika Kisnarini \\ Architecture Department, Institut Teknologi Sepuluh Nopember, Surabaya \\ e-mail: rahardiyanari@yahoo.com; dewi_s@arch.its.ac.id; rika@arch.its.ac.id
}

\begin{abstract}
Rental houses as a place to live is a major needs for factory workers. Liveable rental houses can improve the quality of workers life's in the future, because they have the opportunity to get a livable house in their lives. Therefore, rental houses in industrial areas provided by the private sector for workers should meet livable houses standards. This study was made to determine the feasibility of habitation and evaluate rental housing for workers provided by the private sector, and then formulate the concept of rental houses according to standards or policies for livable houses, the theory of livable houses and the results of research evaluations of rental houses for factory workers in industrial areas. The methods in this research used positivism with primary and secondary data collection techniques through direct observation at the study location, questionnaires for factory workers as tenants, and interviews. who participated in this study were 123 respondents from a total population of 400 units. The concept of decent housing for workers in industrial areas is obtained from the evaluation results of the standard of livable houses, literature studies, and the results of a SWOT analysis. The results of this study, is about the concept of a livable rental houses for workers in an industrial area, including the area of the room in accordance with the provisions of a bunk bed that can occupy four people so that the rental costs can be share by four people, setting the ventilation system with cross ventilation on two sides of the wall for the occurrence of cross ventilation with a ceiling height of 3 meters, the provision of adequate windows for natural lighting during the daytime so as to save electricity consumption. With a air system and good natural lighting will give positive results for the rental house because the house will be far more livable and healthier to live in. This research is expected to be a reference for rental housing owners and the government to make the concept of livable rental housing for workers in industrial areas.
\end{abstract}

Keywords-Rental Houses, Livable, Factory Workers, Industrial Area.

\section{INTRODUCTION}

$\mathrm{F}$ ULFILLING the needs of decent, managed and affordable households for the community related to the community's own responsibilities, appropriate financial planning, especially on a national scale is the task and the way the government in this case is the Ministry of Public Works and Public Housing [1]. However, the basic rights of the people at this time still have not been fulfilled [2]. One of the reasons is the representation of fulfilling the relatively large housing needs (backlog) [3]. This happens partly because it still lacks the purchasing power of the community specifically for Low-Income Communities (MBR) in meeting their housing needs [4].

On the other side, rental houses are generally in an inadequate environment, with inadequate public facilities and unsupported accessibility [5]. Rental homes are generally owned by people who have a good economy [6]. In building a rental house, the owner should pay attention to aspects of livability that are important for the life of factory workers in the future [7]. Great expectations when the needs of sustainable rental homes are met will affect the quality of factory workers who are also classified as low-income people [8].

This study focuses on designing guidelines for the design of livable rental homes where improvements to the budget on physical buildings and sanitation conditions [9]. Both of these aspects become very important because this house deserves priority from the quality of physical buildings and sanitation are met [10].

\section{RESEARCH METHOD}

The approach used in this research is the positivism and primary and secondary data collection techniques through field observations, questionnaires for factory workers as home tenants and homeowners and interviews [11]. Guidelines for the design of sustainable rental homes for factory workers in the industrial area were obtained from a triangulation analysis of sustainable housing standards, literature studies, and research evaluation results [12]

\section{A. Research Strategy}

In this study data collection was carried out using a Likert scale questionnaire. Likert scale questionnaire was given to the owner and labor respondents as tenants with the expectation of the respondents to give their insight into how a rental house is livable. Data obtained from 1 research location, namely settlements in the village of Bangah (123 respondents). The variables in this study are the area of the room, raw materials, lighting, air conditioning, clean water supply, communal toilets, drainage conditions and septic tank conditions.

\section{ANALYSIS RESULT}

To answer the research objectives, a SWOT analysis is carried out where each variable will be translated from strengths, weaknesses, oppportunity and threats. The results of the analysis will be translated into strategies, the first strategy is to realize livability in the physical dimensions of the building. Then the second strategy is to realize livability in the sanitation dimension. Both of these strategies become important factors in the fulfillment of a decent rental house, therefore both the physical dimension of the building and the sanitation dimension must be fulfilled both.

Based on the results of the survey in the field, it was found that the majority of the rooms in the rental house still did not 
The $6^{\text {th }}$ International Seminar on Science and Technology (ISST) 2020

July $25^{\text {th }} 2020$, Institut Teknologi Sepuluh Nopember, Surabaya, Indonesia

meet the proper standard of $9 \mathrm{~m}^{2}$ per person. On the other hand, many tenants who are married have decided to stay in a small rental house because they save on rent. According to the results of the interview the respondents as tenants of the house hope that in the future they will be able to get a rental house with an adequate size but at an affordable rental price.

To be able to help realize sustainable design guidelines in addition to determining the area of space for rental units, is the use of raw materials. The use of lightweight brick material for walls, the roof sector uses lightweight steel roof truss and sandy metal roof coverings. The use of this material is widely associated as a sustainable material because in the construction process minimal waste of construction is wasted, and the application is relatively easy than conventional building materials such as red brick and wood for roof construction that is heavy enough and at risk of termites. Considering that there are termites in the study area, the use of mild steel is considered appropriate because there is no need for special treatment to overcome the problem.

Based on the results of the survey in the field, the tenants of the rental houses still turn on the lights during the day because the window's ability to enter the light during the day is lacking. The cause of the problem is the presence of barriers in the form of trees and neighboring houses that are so close together that they do not make room for sunlight to enter the room. The majority of tenants of rented homes want an improvement in the lighting sector by attempting to close window openings in the hope of getting more sunlight into the room.

Most of the ventilation problems at the research location are handled by the tenant with a fan or exhaust fan, but this does not merely solve the problem, because good ventilation must adhere to a cross ventilation system so that the air inside the room is always exchanged with fresh air from outside. In this rental house using a concrete roster that is quite a lot in the market so it is easy to obtain and installation is easy. Concrete roster mounted on two sides of the wall so that cross ventilation occurs in the room. In addition to the use of roster, window application with Nako glass also helps better air circulation.

Based on survey results in the field, the majority are still bad because the owner only provides water from wells whose water conditions are not good. While some rental houses have provided PDAM water. However, another problem is the absence of sufficient water reservoirs, so that at certain times, especially in the morning, the tenants of the rental houses often run out of water because the small PDAM water supply and the existing reservoirs cannot accommodate the needs of all tenants. The solution to the problem above is by procuring the upper water reservoir and the lower water reservoir.

The existence of toilets can be very crucial because a proper place to live is also assessed from the feasibility of toilets and other supporting areas. If a number of rental houses, as in the study location, are lacking, there will be a queue during the morning and a lack of clean water supply considering that the rental house owner must provide water according to the number of toilets. Then the proposed design guidelines are communal toilets, which each toilet accommodates three rental housing units, very far compared to the existing condition of five rental housing units for one toilet.

At present the condition of the septic tank in the study sites is mostly still using conventional septic tank. In addition, the appropriate placement is also rarely considered by homeowners when in the construction phase. The problem that often occurs is that the septic tank is easily filled and the location is close to the well. This can pollute clean water sources and have an impact on the environmental health of rental homes. So the design guideline for this septic tank in a rented house is the use of a biofilter septic tank that has better processing of waste and is easy to install, as well as the placement of a septic tank that is far from the water source, which is a lower water reservoir.

The design guideline that results from the analysis for the drainage of rental homes is to provide a small ditch around the building to drain rainwater from the land of the house to the ditch along the road. This small ditch in addition to rain drainage can also prevent damp house swalls due to puddles of water that cannot flow into large drains. Meanwhile, roadside gutters use culvert box gutters, which are now commonly used because of their rapid processing so that they do not interfere with residents' activities compared to conventional brick making.

\section{CONCLUSION}

Based on the findings of this study, it can be concluded that in an effort to achieve rental housing for livable workers, the two absolute dimensions must be fulfilled namely, the physical dimension of the building and the dimension of sanitation. The achievement of livable rental homes in the physical dimensions of the building and sanitation is very dependent on the willingness of the rental homeowners to repair. In the case of a rented house that has been built, the wide aspect of the room becomes difficult to fulfill because it will be very burdensome for the owner of the rental house in its repairs. While other aspects can be met without dismantling most of the existing buildings. The success of implementing design guidelines on livable rental homes for factory workers requires synergy from owners and tenants as users, the government as policy makers or policy makers and the Maspion factory in the realization of policies set by the government.

\section{REFERENCES}

[1] Ball, M., Lizieri, C., and MacGregor, B., The Economics of Commercial Housing Market. London: Routledge, 1998.

[2] Frick, H., Cooper, Rumah Sederhana: Kebijaksanaan Perencanaan dan Konstruksi. Yogyakarta: Karnisius, 2003.

[3] Rapoport, Amos, Human Aspect of Urban Form. Oxford; Pergamon Press, 1977

[4] Sofyandi, Herman dan Garniwa, Iwa. Perilaku Organisasional. Yogyakarta: Graha Ilmu, 2007.

[5] Turner, Jhon FC dan Robert, Freedom to Built Dweller Control of Housing Process. New York: The Macmillan Company, 1972

[6] Untermann, Richard dan Small, Robert, Site Planning for Cluster Housing. New York: Van Nostrand Reinhold, 1977 